\title{
Features of the Art Market in Russia
}

\author{
Julia Gnezdova \\ Department of Economics \\ Smolensk State University \\ Smolensk, Russia
}

\author{
Elena Matveeva \\ Department of Economics \\ Smolensk State University \\ Smolensk, Russia
}

\begin{abstract}
The art market (the marketing of art objects) is a complex, multilevel, multifunctional, socio-cultural phenomenon. This article is an analysis of how entrepreneurship in art which resulted from the integration of two spheres - culture and business - is carried out. Today, works of art have become a commodity of trade and investment. Having become perspective investment tools, relevant research includes the assessment of the extent of forming of market relationships and the strategies for the promotion of art culture.
\end{abstract}

Keywords-culture; state; cultural policy; art market; entrepreneurship

\section{INTRODUCTION}

As part of the rich cultural heritage of our country, there is a long history and tradition of the art market. Currently, there exists an entrepreneurship culture in the arts - a particular type of human activity that resulted from the integration of two spheres, culture and business. This area of activity has characteristics of the formation, development and transformation of market relations. This entrepreneurship culture has developed and been implemented within the framework of the industrial and post-industrial development model of society. Entrepreneurship culture has an ambivalent nature.

Relevance of research is determined by the fact that the cultural product, according to A. Breton, is a luxury, but, simultaneously, it is a commodity of mass consumption. A similar combination concerning a simple product is impossible. A cultural product is seldom consumed repeatedly, and manufacturing cost doesn't influence pricing. A simple product is destroyed in the course of consumption, i.e., items deteriorate, foods are eaten. But the cultural product increases the value in the act of consumption, i.e., as more people visit a museum or a concert, read the book, viewed the program, their social importance becomes higher.

\section{PURPOSES AND METHODS}

The purpose of this work is the summarization of theoretical bases and systematization of methods for promoting art products from the artist to the public. In the world today, there is a complex and multi-level infrastructure of the art market, of which key features are the producers of an art product and its consumers. Among elements of the art market, the art museums (both state-owned and private) have special value, being organizers of cultural projects. [2].
The publication includes the analysis of the available academic literature and results of research of trends in the development of the art market in Russia and abroad. The empirical base used in this scientific work can be used as historiographic material in studies of subsequent developments. In this work, statistical data from the Ministry of Culture of the Russian Federation, collected monographs, and reports and data from empirical research of Russian and foreign scientists were used [1].

\section{RESULTS AND DISCUSSION}

\section{A. Development of Entrepreneurship in the Arts-General Statistics}

Formation of market practices regarding objects of art took place in difficult historical conditions. In the period of the Russian nobility, basic traditions of collecting were created. Russian artists had numerous customers, and the artists organized numerous creative associations, each of which promoted the arts. Differentiation of creative methods promoted the development of competition which is one of the main characteristics of the free market. With the inception of the Soviet era, free turnover of works of art practically ceases to be performed. The state developed the ideological base for culture. The ideas of socialist realism, at the heart of which nationality, moral substance, and commitment to classical realism, defined the main and sole consumer. Post-Soviet era development of modern art in Russia can be divided into stages: [1]

Stage I (1985-1990) - Finding of freedom

Stage II (1990-1993) - Emergence of market infrastructure

\section{Stage III (1993-1999) - Crisis}

Stage IV (the 2000th years) - New arising

The first phase was 1985-1990. The artists' acquisition of creative and institutional freedom. The state no longer controlled art. This period was fairly painless, thanks to the appearance of the rabid demand for Russian and Soviet art in the West. The "Russian boom" and the low prices of art opened the Iron Curtain. This evoked great interest in Western collectors who originally bought it as social art and Socialist Realism.

During this period, the artist, because of undeveloped market relations, was represented by others in the market, i.e., 
the gallery owner and the manager. The atmosphere of utter chaos and arbitrary behavior, and the lack of a sophisticated art market were conditions which led to the fact that many creative artists emigrated abroad and there were absorbed into Western culture. At the same time, lack of infrastructure of the art market and the hierarchy of art life under the new conditions added to the fact that the Western investors' desire to participate in art life of the newly created Russian society was gone. It emphasized the need for the creation of a native infrastructure of the art market. In 1990, the first galleries appeared, i.e., Rigina, M. Gelman's Gallery, "School", "Gift".

The second stage of $1990-1993$ is considered to be the active construction period of the Russian art market. Legalization provisions for the seller and buyer, and their separation from government institutions, allowed the new art entrepreneurship to perform the distribution of art objects in economic terms. There were numerous intermediaries conducting the activities in the sphere, such as galleries, antiquarian salons, and auction houses. Such development is quite understandable. Under free market conditions, the value of the work is determined, as a rule, by its market value. Subsequent developments mediated between the artist and the public. At this time also, as various art publications and magazines appeared, the expert community was created, the role of the critic increased in importance along with the development of the modern market. Art values were perceived not only as spiritual and cultural objects, designed to satisfy esthetic needs and personal interests, but also as commercial values, that is, having a determined price. The art market was intended not only to perform the function of mediating between the artist and consumer, but also to provide timely and exact information on goods quantity and services, in order to meet requirements and requests of the buyer across a wide range of goods. Along with development of the internal market, the share of domestic art in the international art market considerably increased. The number of works of masters of domestic schools likewise increased.

The third stage of 1993-1999 was a period of crisis in the development of art markets in Russia. As galleries, as well as many social and economic institutions of that time, had very indistinct ideas of how it is necessary to do business, their activities were based on theoretical models; there wasn't enough practical experience. At the same time, owing to the insignificant expenses and the presence of inexperienced but enthusiastic people (principally artists), many were motivated to work on the creation of the new industry system of relationships. This volunteer image became noticed by corrupt officials and criminals. During this period, modern Russian art exhausted its values. No major new artist or an art initiative appeared. It was felt the artistic environment has lost that level of dynamism and reflection which marked the beginning of the 1990s.

The fourth stage was when the art life wakened in the $21^{\text {st }}$ Century after long years of stagnation. New galleries, analogous with the European creative centers, are created. The market profile and non-core media art increased. The public began to support art more willingly. Federations and the unions of professional subjects of the art market were created. However this is only an initial stage of the Russian art market. It is still far from the establishment of the sophisticated relationships and from the transition to a stage of sustainable development to the art market in our country. The main problems consist, primarily, in lack of legislation and support from the state.

\section{B. Assessment of the World Market of Arts Objects}

In the world market of objects of art, sales volume is traditionally divided into two major sectors - auctions (48\%) and galleries and art dealers $(52 \%)$. The main turnover of objects of art is in the form of gallery sales, and, in the upper price segment, of private dealers. It is accepted that the auction is a form of the sale of objects of art which will determine the fair price of an art object. Around the world, there are intensive fights between galleries for the right to sell a subject or an artist. Although this provokes some tension and hostility between dealers and auctions, nevertheless, they cooperate and supplement each other. As a result, all parties benefit from this mutually advantageous symbiosis. Auctions receive as much as a third of contracts for sales to dealers and galleries. Dealers have the chance to implement a higher price, than the auction would obtain. The attraction of the auction sale of art forms is especially obvious for the seller and buyers of antiques.

Due to the lack of stability in this market, many artists are forced to move to other professional fields, which is unfortunate as all costs for their promotion are not justified. The most advanced country in the development of the entrepreneurial activities in culture and art is the USA. Other markets pale in comparison with New York City - and the greatest part of the income of the world art market is from this city. It is due to an objective reason. The USA declines to support culture and art at the same level of the state support of 200 years ago. Instead, it has created conditions under which the organizations of culture and art actively and fruitfully interact, especially with business. In the European countries, the state patronizes this sphere more actively. Following a current trend, the European states began to adopt laws, transferring a part of the issues of culture directly to business. Modern Russian businesses with a strong financial position currently have a unique experience not only of surviving, but also powerful development under the conditions of free competition. This unique experience can become invaluable as Russian businesses enter into the sphere of culture and art.

According to the annual overview of the world art market published in March, 2016 by the Artprice and Art Market Monitor of Artron (AMMA) companies, for the last decade the market for art grew by $212 \%$. This significant increase is largely due to the globalization of the art market, as well as growth in demand in its most expensive segment. The total sales volume of works of art in terms of money in the world grew almost three times whereas the number of transactions increased less than by a quarter. And here the term of ownership of objects of art was sharply reduced, on average to several years. This means that the same paintings and sculptures of the new collector were resold at a higher price. [8] 
While the Chinese art market undergoes a phase of deep reorganization, the cumulative share of the USA and Great Britain increased to $65 \%$ of the world auction market for modern art. A quarter of all sales of works of modern artists passes through London and New York.

The United States is currently the strongest market for contemporary art; it accounts for $38 \%$ of the global market. Of the $\$ 582$ million, almost $95 \%$ of this amount is generated in New York. For last year, the turnover falling on the USA in this segment of the market was reduced by $24 \%$, but they still remain a leader. A quarter of the world market of modern art falls to the share of Great Britain. It also was reduced by $10 \%$, to $\$ 399$ million, but this amount is $\$ 40$ million more than China which lost the second place in a segment of the modern art, but remained the indisputable leader of the world art market in general.

The European market for modern art in general wasn't too subject to decay, and in some cities even grew: Vienna (\$7.3 million), Amsterdam (\$4.9 million), Berlin ( $\$ 4.2$ million), Brussels (\$3.2 million) and Milan (\$1.6 million). It is generally connected with especially prestigious biddings in which these cities have considerable weight. At the same time, the market of modern art in Germany was reduced by $19 \%$, to $\$ 17.6$ million, and the share of not-sold lots on the German biddings increased from $44 \%$ to $55 \%$. The market of modern art of France occupies the fourth place with market turnover of $\$ 41.4$ million. This was reduced by $6.8 \%$, a figure which seems predictable in present market conditions. Amounts of transactions in France remained high, and the country managed to maintain the level of items in the highend market segment.

\section{Possibilities of the Russian Art Market}

In Russia, there is not yet an economy in which people are ready to spend money with confidence to satisfy $\mathrm{n}$ the purchase of the highest levels of art. In fact, this opens opportunities for the Russian art market as the space for works of art in private collections is available. Creation of the complex market relations and promotion in the sphere of culture of arts is necessary to increase market value of works of artists, having turned them into a perspective investment tool. For businesses, the artist offers the work of art in an exhibition. For this purpose, culture and arts shall come to rely upon business and technology, namely: [6]

- The modern advanced and approved technologies of management;

- Marketing tools of research of the markets;

- Bases of communication and management;

- Productive experience of the integrated marketing technologies in working with target audiences for promotion of new products, services, and brands;

- Development of technologies of branding;

- Experience in sponsoring and fund raising.

The prospects of development of the Russian art market exist and are quite obvious. Increase in number of professionals in this sphere is the highest priority now. The art market is a complex, multilevel, multifunctional sociocultural phenomenon. At the moment, the investment of money goes to art in two main directions, each of which has subtleties which for certain reasons suit only some investors:

1) A direct investment of money in cultural values. The investor and independent artist work with the object of increasing its value and cost. It is a rather difficult and labor-intensive process because the investor himself must be a qualified specialist in the assessment of objects of art. The investor must be able to quickly estimate its starting price and the prospects of its growth. Moreover, participation in various exhibitions and other specific actions is necessary. Otherwise, the price of an object will stand still, and sometimes may show a downward tendency that it is absolutely inadmissible for this type of investments.

2) The second main direction is the mediated investment into art: This type has practically no shortcomings. Entrance into the investments market is available to everyone, owing to the fact that shares are purchased. Thus, the investment entity owns a portfolio. This allows individuals to invest money in objects of art whose cost is high. [4] According to experts, investment of capital in paintings and antiques can provide income exceeding average deposit rates due to natural value increase of artifacts owing to their "aging". Besides, similar investments are most often not subject to depreciation. In some cases, profitability of similar investments can be estimated at hundreds of percent. (It can happen, for example, to the early works of the famous masters purchased before they became popular, or grouped with pictures of unidentified authors.) At the same time that possession of objects of art brings dividends to the equity of the owner, it also strengthens his social status. The total turnover of the art market of 2015 is estimatee at $\$ 63.8$ billion. From data for 2016, a number of analysts believe that the market could be reduced to $\$ 60$ billion. Thus, the 2016 market decreased by $7 \%$ in comparison with previous year. A significant role in this was played by the juicy scandals and revelations about dealers in art. A crisis of confidence and outflow of investors from this sphere was the consequence.

The most profitable segments of the art market are traditionally considered to be the Impressionists and the art of the twentieth century. At the end of 2015 the most successful was post-war and contemporary art; this accounts for $46 \%$ of sales, while total turnover amounted to $\$ 6.8$ billion. The second most important category was the art of Impressionism and Modernism which had 30\% of sales, and whose total turnover was valued at $\$ 4.5$ billion.

It is hardly possible to call the art market an area for easy investments. It is necessary to be guided in the history of art and the prices of works of specific artists. Investors must constantly watch hundreds of auctions which take place daily in the different parts of the world; sometimes they literally pursue masterpieces and must be able to negotiate with the previous owner of work (the collector, the artist, or 
their heirs) - and there are frequently "difficult clients". Additionally, not everyone will have personal relationships with experts on specific artists. To the person far from the world of art, is not easy to deal with predictions of growth or decline in the demand for certain artists, to analyze sales statistics, and to determine authenticity of the work and its investment appeal.

TABLE I. STATISTICS OF THE RUSSIAN AUCTION MARKET

\begin{tabular}{|c|l|l|l|l|}
\hline Indicator & \multicolumn{4}{|c|}{ Year } \\
\cline { 2 - 5 } & $\mathbf{2 0 1 3}$ & $\mathbf{2 0 1 4}$ & $\mathbf{2 0 1 5}$ & $\mathbf{2 0 1 6}$ \\
\hline $\begin{array}{c}\text { Amount of sale at internal auctions, } \\
\text { \$ million }\end{array}$ & 21 & 14 & 4.6 & $6.6^{* *}$ \\
\hline $\begin{array}{c}\text { Share of the sold lots in domestic } \\
\text { market, \% }\end{array}$ & 39 & 41 & 35 & $46^{* *}$ \\
\hline $\begin{array}{c}\text { Amount of sale at world auctions, } \\
\text { \$ million }\end{array}$ & 525.1 & 677 & 572.6 & $274^{* *}$ \\
\hline
\end{tabular}

a. $* *$ Provisional figure which doesn't include results of the auctions of the second half of December.

${ }^{\text {b. }}$ Source: https://artinvestment.ru

The relatively small size of the market is coupled with prohibitive cross-border trade legislation still firmly "defend" our market from foreign participants. None of the foreign auction houses conduct trading in Russia.
The results of 2016 is small. "Fig. 1" shows all consumer activity. The base of buyers gradually expands, and is a factor of long-term stability of business.

The market for modern art adapted to new conditions; auctions ceased to pursue new records and concentrated their attention on works of average price and from the lower part of the high-end segment. It directly affected sales patterns and it allowed price stabilization. $6 \%$ of the sold lots involved works worth over $\$ 50$ thousand. During the corresponding period of the previous year, there were $8 \%$ such works.

The amount of the auction market for the considered period made $\$ 1.5$ billion compared with $\$ 2.1$ billion during the corresponding period of the previous year. The market was reduced more than by a quarter, but the long-term trend of development remains positive, reflected by growth of $1370 \%$ since 2000 . After four years of continuous turnover growth, a segment of the modern art market began to be reduced sharply in the first half of 2015, and the second half of year continued this tendency. Overall fall of the market for 2015 was $39 \%$. After outstanding results of 2013-2014, correction in the market for modern art became inevitable. Collectors of contemporary art have become more cautious.

\section{ARTIMXba-LOCAL}

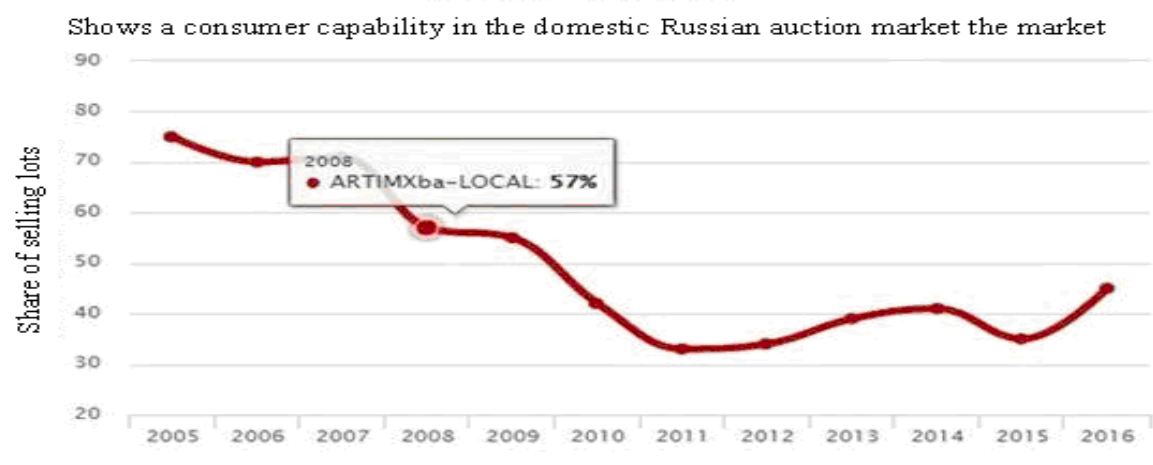

a. Source: https://artinvestment.ru

Fig. 1. Dynamics of consumer activity. The proportion of lots sold at auction in Russia,\%

\section{CONCLUSIONS AND RECOMMENDATIONS}

Russian art available for the world art market represents only very small part of that huge art wealth actually present. The market of art is the very difficult system, integrating functions of its various components: artists, auctions, galleries, museums, dealers, collectors, entrepreneurial and financial worlds, mass media, politicians, economists, customs and tax authorities.

Familiarizing of the individual with this culture occurs through socio-cultural activities. [8] The art market in this sense is a striking example of vigorous and diverse sociocultural activity which is implemented during various cultural and historical eras in corresponding specific forms.

\section{REFERENCES}

[1] Dolgin A. A. Culture and market: current trends [Text]. / A. A. Dolgin. - M.: Avesta, 2009. - 420 pages.

[2] Zhideleva KA Kirillov NB The art market as a sociocultural phenomenon // In the world of science and art: Philology questions, art and culture: Sat. Art. on the mater. XVIII Int. scientific-practical. Conf. Part I. - Novosibirsk: Seebach, 2012

[3] How to sell art: Sat. Art. / Sost. and edition Joseph V. Melillo; The Lane from English V. O. Babkov. Novosibirsk: Sib. chronograph, 2001. - 195s.

[4] Kolber F., Evrar And. Art management science of the third millennium//Art manager. - 2002. - No. 3. - Page 3-6.

[5] Lytvyna L. P. Art market of the modern art of Russia. First steps: (The review tsentrat, the periodical presses of the ninetieth years)//the Panorama of cultural life of the Russian Federation: Inform. M, 2001. - the Issue 2. - Page 32 - 60.

[6] Popkova K. E. World market of objects of art: specifics, structure, dynamics//International student's scientific bulletin. - 2015. - No. 4-3. - Page 426-429;

[7] Hangeldiyeva I. G. Features of control in культуре.//Applicationoriented cultural science. M., 2010 
[8] Guide to the Contemporary Art Market in Asia // the Artprice report 11/01/2011 Electronic resource. URL: http://web.artprice.com/ami/ami.aspx 